\title{
KELIMPAHAN DAN KERAGAMAN BAKTERI RIZOSFER TANAMAN PISANG SERTA HUBUNGANNYA DENGAN KEJADIAN PENYAKIT LAYU FUSARIUM
}

\author{
Dr. Widya Sari, SP., MP. *, Irwan Irawan, SP. **
}

\begin{abstract}
ABSTRAK
Penyakit layu yang disebabkan oleh cendawan Fusarium Oxyporum Schlecht f. sp. cubense (Foc) (E.F. Smith) Snyder dan Hansen, sampai saat ini masih tercatat penyakit yang paling berbahaya dan mengancam industri pisang dunia. Dalam praktek budidaya tanaman selalu dipengaruhi oleh keberadaan mikroorganisme rizosfer seperti bakteri, cendawan dan protozoa. Mikroorganisme rizosfer biasanya lebih banyak dan beragam dibandingkan pada bukan tanah rizosfer. Mikroorganisme rizosfer dapat mempengaruhi pertumbuhan tanaman, bermanfaat atau menjadi patogen bagi tanaman. Penelitian mengenai kelimpahan dan keragaman bakteri rizosfer pisang perlu dilakukan sebagai sumber informasi awal yang dapat menggambarkan hubungannya dengan kejadian penyakit layu Fusarium pada tanaman pisang dibeberapa sentra penanaman pisang. Pengamatan dilakukan di 9 wilayah pengambilan sampel tanah diantaranya 3 kecamatan di Cianjur dan 1 kecamatan di Cipatat kabupaten Bandung Barat dengan minimal luas tanaman kebun pisang $300 \mathrm{~m}^{2}$, adapun wilayah tanah yang diambil sampel tanah di Cianjur yaitu: Angke 1, Aangke 2, Baru, Balandongan, Kabandungan, Gekbrong, Salapuncak dan 2 wilayah yang diambil dari Cipatat Kabupaten Bandung Barat Cisadang dan Bungur. Dari hasil isolasi rhizobakteri yang dilakukan pada 9 sampel tanah tersebut didapatkan 31 koloni bakteri. Data diolah dengan analisis korelasi dan regresi, sedangkan untuk pengambilan keputusan dilakukan dengan membandingkan $r$ hitung dan $r$ table. Dari hasil pengamatan kelimpahan bakteri rizosfer didapatkan hasil bahwa terdapat pengaruh jumlah bakteri tanah terhadap kejadian penyakit layu fusarium artinya semakin bakteri rizosfer melimpah maka semakin mendukung dalam kejadian penyakit layu fusarium, tetapi dari hasil pengamatan keragaman bakteri rizosfer di dapatkan hasil bahwa tidak ada pengaruh keragaman terhadap kejadian penyakit layu fusarium
\end{abstract}

Kata Kunci : Kelimpahan, Keragaman, Bakteri Rizosfer, Penyakit Layu Fusarium

\section{ABUNDANCE AND DIVERSITY OF BANANA PLANT RHIZOSPHER BACTERIA AND IT'S RELATIONSHIP WITH FUSARIUM WILT DISEASES}

\begin{abstract}
Wilt disease caused by Fusarium oxyforum f.sp. cubense (Foc) (E.F. Smith) Snyder and Hansen, still recorded as the most risk and threaten banana world industry. In plant culture practise always influenced by presence of rbizosphere microorganism population which is ussualy much and diverse compared to soil non rizosphere. Microorganism can effect plant growth, helpful or harm to plant. Research regarding abudance and diversity of bacterial banana rbizosphere is needed as an early information which can describe by its correlation with fusarium wilt desease in banana plant. The observation taken in nine sampling location such as three sub-districts in Cianjur, and 1 sub-district in Cipatat, Bandung Barat regency with $300 \mathrm{~m}^{2}$ farm minimum area. Nine sampling location are Angke 1, Aangke 2, Baru, Balandongan, Kabandungan, Gekbrong, Salapuncak, Cisadang and Bungur. There were 31 isolates of rbizobacteria from that soil sample. Data processed was with correlation and regression analysis, and for decision making done by compare $r$ count and $r$ table. Research result showed there were close relationship between abudance of rbizobacteria with fusarium with wilt disease incidence, but there was no correltion between diversity of rbizobakteria and wilt disease incidence.
\end{abstract}

Key words: Abudance, Diversity, Rhizosphere Bacteria, Banana Fusarium Wilt disease.

*) Dosen Fakultas Sains Terapan Universitas Suryakancana

**) Alumni Fakultas Sains Terapan Universitas Suryakancana 


\section{PENDAHULUAN}

Pisang merupakan tanaman buah-buahan tropis yang berasal dari Asia Tenggara, Brazil dan India. Pisang memiliki peranan penting di Indonesia karena merupakan buah yang paling banyak dikonsumsi oleh semua masyarakat dibanding dengan buah-buahan lainnya.

Pusdatin Pertanian (2009), terjadi kesenjangan antara jumlah konsumsi pisang nasional dengan jumlah produktivitas pisang. Balai Besar Pengkajian dan Pengembangan Teknologi Pertanian (2008), menerangkan bahwa kesenjangan produktivitas tersebut terutama disebabkan oleh teknik budidaya yang tidak tepat dan tingginya gangguan hama dan penyakit terutama oleh serangan dua penyakit paling berbahaya dan mematikan, yaitu penyakit layu bakteri atau penyakit darah dan penyakit layu fusarium.

Penyakit layu yang disebabkan oleh cendawan Fusarium oxyporum Schlecht f. sp. cubense (Foc) (E.F. Smith) Snyder dan Hansen, sampai saat ini masih tercatat sebagai penyakit paling berbahaya dan mengancam industri pisang dunia. Patogen tersebut menyebabkan penyakit layu atau yang lebih dikenal dengan penyakit layu Panama (Ploetz dan Pegg, 1997).

Fusarium oxyporum f. sp. cubense merupakan patogen penghuni tanah yang mempunyai kemampuan hidup sebagai saprofit, dapat mendegradasi lignin dan komplek karbohidrat, juga dapat berasosiasi dengan bahan organik tanah, memiliki ras fisiologi yang berbeda dan dapat menimbulkan penyakit yang bersifat monosiklik sehingga strategi pengendalian yang efektif hingga kini belum ditemukan. Disamping itu, patogen dapat bertahan dalam berbagai jenis tanah sampai puluhan tahun walaupun tanpa inang (Kistler, 2001).

Menurut Nurhayati (2011) faktor lingkungan abiotik dan biotik mempunyai pengaruh terhadap perkembangan penyakit tanaman. Lingkungan biotik meliputi mikroorganisme seperti mikroflora. Keberadaan mikroorganisme yang berada di rizosfer berpengaruh terhadap perkembangan patogen yang menyerang tanaman tersebut. Mikroorganisme tersebut menggunakan eksudat akar tanaman. Keberadaan mikroorganisme ada yang bersifat negatif, positif dan ada juga yang bersifat netral bagi patogen. Keberadaan mikroorganisme disekitar tanaman yang bersifat negatif bagi patogen merupakan prinsip yang digunakan oleh para ahli dalam pengendalian penyakit tanaman secara biologis, biasanya mikroorganisme ini memiliki kemampuan untuk memproduksi biofilm pelindung atau antibiotik yang berperan sebagai pengendalian hayati terhadap patogen (Bais et al., 2006).

Pengaruh positif mikroorganisme bagi patogen dapat berupa simbiosis antara mikroorganisme antagonis dengan mikroorganisme itu sendiri. Sehingga mampu meningkatkan aktivitas mikroorganisme patogen. Pengaruh netral mikroorganisme bagi patogen yaitu keberadaan mikroorganisme tersebut tidak memberikan pengaruh baik positif maupun negatif terhadap patogen tersebut (Ladygina, 2005). Untuk itu, diperlukan penelitian mengenai hubungan kelimpahan dan keragaman jenis Bakteri yang tumbuh di areal rizosfer pisang dengan kejadian penyakit layu fusarium.

Tujuan dilaksanakannya penelitian ini adalah untuk mengetahui hubungan antara kelimpahan dan keragaman bakteri rizosfer serta hubungannya dengan kejadian penyakit layu fusarium pada tanaman pisang.

Berdasarkan latar belakang di atas, dapat diambil hipotesis, yaitu $\mathrm{H}_{0}=$ Tidak terdapat hubungan antara kelimpahan bakteri rizosfer dengan kejadian penyakit layu fusarium. $\mathrm{H}_{1}=$ Terdapat hubungan antara kelimpahan bakteri rizosfer dengan kejadian penyakit layu fusarium $\mathrm{H}_{0}=$ Tidak terdapat hubungan antara keragaman bakteri rizosfer dengan kejadian penyakit layu furium. $\quad \mathrm{H}_{1}=$ Terdapat hubungan antara keragaman bakteri rizosfer dengan kajadian penyakit layu fusarium.

\section{BAHAN DAN METODE}

Penelitian ini dilaksanakan pada bulan Maret 2014 hingga Juni 2014. Kegiatan penelitian dilaksanakan di Laboratorium Fakultas Pertanian Universitas Suryakancana Cianjur, dan sepuluh kebun petani di empat kecamatan (Cugenang, Sukaresmi, Gekbrong, dan satu kecamatan di Kabupaten Bandung Barat, yaitu kecamatan Cipatat). Kriteria lokasi pengambilan sampel yaitu memiliki luas lahan \pm $300 \mathrm{~m}^{2}$, menanam varietas pisang ambon, dan sudah menanam pisang ambon $<2$ tahun.

Adapun lokasi pengambilan sampel dapat dilihat pada Tabel 01. 
Tabel 01. Lokasi pengambilan sampel tanah yang diamati

\begin{tabular}{llc}
\hline No & \multicolumn{1}{c}{ Nama Tempat Pengambilan sampel } & Kode yang digunakan untuk sampel tanah \\
\hline 1. & Salapuncak & $\mathrm{SP}$ \\
2. & Kabandungan & $\mathrm{KB}$ \\
3. & Balandongan & $\mathrm{BD}$ \\
4. & Angke 1 & $\mathrm{AK}_{1}$ \\
5. & Angke 2 & $\mathrm{AK}_{2}$ \\
6. & Baru & $\mathrm{BR}$ \\
7. & Bungur & $\mathrm{BG}$ \\
8. & Cisadang & $\mathrm{CS}$ \\
9. & Gekbrong & $\mathrm{GK}$ \\
\hline
\end{tabular}

Sumber : hasil observasi di lapangan.

Bahan yang alat digunakan pada penelitian ini adalah:

a) Untuk kegiatan pengambilan sampel tanah, alat dan bahan yang digunakan meliputi: Sekop atau sendok tanah, bor tanah, kantong plastik contoh, pisau/gunting, ember atau baskom plastik, kotak es, alkohol 90-95\%, kertas/karton label, bahan dan peralatan yang akan digunakan harus dalam kondisi bersih dan steril (Husen, 2007).

b) Untuk penetapan kadar air tanah alat dan bahan yang digunakan meliputi kaleng untuk mengukur kadar air, timbangan, oven, desikator, contoh tanah.

c) Untuk kegiatan enumerasi bakteri alat dan bahan yang dibutuhkan adalah tabung reaksi, erlenmeyer, cawan petri, pipet mikro ukuran $100 \mu \mathrm{l}$, tip ukuran $1 \mathrm{ml}$, batang penyebar (spreader), vortex, timbangan analitik, sampel tanah, aquades, dan Potatoes Dextrose Agar (PDA).

d) Untuk kegiatan pengolahan data alat yang diperlukan adalah alat tulis, komputer/

laptop, kamera digital.

Metode penelitian yang digunakan dalam penelitian ini adalah teknik ekploratori, yaitu teknik penelitian yang dilaksanakan untuk menggali data dan informasi tentang topik atau isu-isu baru yang ditujukan untuk kepentingan pendalaman atau penelitian lanjutan.

\section{HASIL DAN PEMBAHASAN}

Dari hasil pengamatan di sepuluh lokasi pengambilan sampel didapatkan data intensitas serangan penyakit fusarium yang beragam, seperti yang disajikan pada Tabel 02 .

Tabel 2. Data Intensitas Penyakit di 9 Lokasi Pengambilan Sampel.

\begin{tabular}{|c|c|}
\hline Sampel Tanah & Kejadian Penyakit (\%) \\
\hline $\mathrm{AK}_{1}$ & 70 \\
\hline $\mathrm{AK}_{2}$ & 70 \\
\hline $\mathrm{BD}$ & 40 \\
\hline $\mathrm{BG}$ & 10 \\
\hline $\mathrm{BR}$ & 40 \\
\hline CS & 30 \\
\hline GK & 10 \\
\hline $\mathrm{KB}$ & 20 \\
\hline SP & 2.5 \\
\hline $\begin{array}{l}\text { Sumber : Hasil pengamatan di lahan petani pisang } \\
\text { Dari tabel 2. yang telah tersaji diatas } \\
\text { menunjukan bahwa dari Sembilan wilayah } \\
\text { perkebunan pisang menunjukan intensitas } \\
\text { serangan penyakit berbeda-beda, serta dapat } \\
\text { dilihat intensitas serangan penyakit yang paling } \\
\text { tinggi yaitu pada wilayah angke } 1 \text { dan angke } 2 \\
\text { sebesar } 70 \% \text { sesuai survey dilapangan disekitar } \\
\text { tanaman pisang banyak terdapat gulma, dan } \\
\text { kebun yang tidak terawat, sedangkan wilayah } \\
\text { intensitas serangan penyakit yang paling rendah } \\
\text { yaitu wilayah salapuncak, sebesar 2.5\%, di } \\
\text { wilayah ini petani telah melaksanakan Standard }\end{array}$ & $\begin{array}{l}\text { ambon di sepuluh lokasi pengambilan sampel } \\
\text { Operating Procedure (SOP) penanaman pisang } \\
\text { dengan baik sehingga di sekitar tanaman pisang } \\
\text { tidak terdapat gulma dan petani sudah } \\
\text { menggunakan pemberian agen antagonis seperti } \\
\text { Trichoderma sp. dan Gliocladium sp. pada lubang } \\
\text { tanam. } \\
\text { Penyakit pada tanaman akan mudah } \\
\text { menyerang tanaman apabila lingkungan yang } \\
\text { mendukung seperti banyaknya gulma disekitar } \\
\text { tanaman dan kurangnya pemupukan sehingga } \\
\text { akan menimbulkan persaingan unsur hara bagi } \\
\text { tanaman utama, hal ini menyebabkan tanaman } \\
\text { utama menjadi lemah dan mudah terserang }\end{array}$ \\
\hline
\end{tabular}


penyakit layu fusarium. Selain itu, gulma juga dapat menjadi inang alternative bagi cendawan Foc.

Penyakit Layu Fusarium menunjukkan gejala yang khas yaitu: terjadi penguningan di tepi daun pada daun-daun yang lebih tua (gejala ini awalnya sulit dibedakan dari kekurangan kalium, terutama pada kondisi kering atau sejuk). Gejala menguning berkembang dari daun tertua menuju daun termuda. Daun-daun yang terserang secara berangsur-angsur layu pada tangkainya atau patah pada dasar ibu tulang daun, sehingga menggantung ke bawah menutupi batang semu. Rata-rata lapisan luar batang palsu terbelah dari permukaan tanah atau terjadi retakan memanjang pada batang semu. Pada bagian dalam apabila dibelah, terlihat garis-garis coklat atau hitam menuju ke semua arah, dari batang (bonggol) ke atas melalui jaringan pembuluh ke pangkal daun dan tangkai. Berkas pembuluh akar tidak berubah warnanya, namun sering akar tanaman sakit berwarna hitam dan membusuk (akan tampak pada tanaman berumur 5 - 10 bulan)

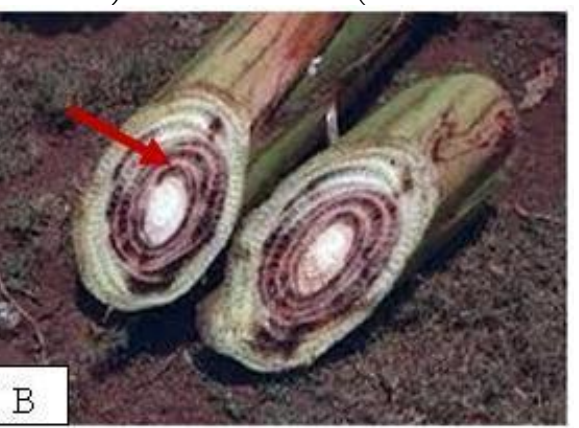

Gambar 1. Gejala layu Fusarium pada tanaman pisang. (A) Gejala kuning pada daun; (B) Berkas pembuluh berwarna coklat kehitaman.

Pada beberapa kultivar, daun-daun pada tanaman yang terinfeksi berwarna sangat hijau sampai daun rebah dan menjadi layu. Daun daun termuda menampakkan gejala yang paling akhir dan sering kali berdiri tegak. Pertumbuhan tanaman berhenti, daun-daun yang baru muncul berkurang sangat tajam dan nampak berkerut semu. Tidak terdapat gejala patogenik pada buah, akan tetapi serangan penyakit dapat menurunkan kualitas dan kuantitas buah (Ploetz dan Pegg 2000).

\section{a. Hubungan kelimpahan bakteri rizosfer dengan \\ kejadian penyakit layu fusarium}

Hasil analisis regresi dan korelasi antara kelimpahan dengan Intensitas serangan penyakit layu fusarium dengan bantuan software Minitab versi 16 menunjukkan hubungan seperti berikut ini :

$$
\mathrm{Y}=7.456+40.69 \mathrm{x}
$$

Dengan nilai $\mathrm{r}$ (koefisien korelasi) sebesar $=$ (0.728)
Pada taraf kepercayaan sebesar 95\% dan $n=9$ harga $\mathrm{r}$ table $=0.666$ nilai $\mathrm{r}$ hitung menunujukan bahwa lebih besar dengan nilai $r$ tabel $(0.728>0.666)$ sehingga $\mathrm{H}_{0}$ ditolak $\mathrm{H}_{1}$ diterima. Artinya "Terdapat hubungan antara kelimpahan bakteri rizosfer dengan kejadian penyakit layu fusarium"

Artinya semakin melimpah bakteri rizosfer pada tanah semakin mendukung dalam terjadinya penyakit layu fusarium.

Kelimpahan bakteri rizosfer tanaman pisang (Gambar 2) dengan kejadian penyakit memiliki hubungan positif, dengan demikian kedua variable yang penulis lakukan memiliki hubungan yang erat. Artinya jika kelimpahan bakteri rizosfer tanah meningkat, maka akan membantu kenaikkan penyakit layu fusarium dengan kata lain bahwa antara bakteri rizosfer tanaman pisang dengan penyakit layu fusarium saling membantu di dalam tanah dalam pertumbuhan penyakit.

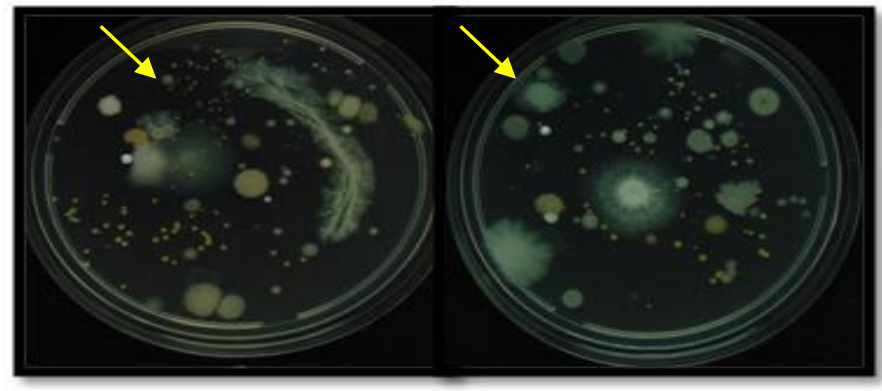

Gambar 2. Koloni bakteri rizosfer tanaman pisang

Kelimpahan Dan Keragaman Bakteri Rizosfer Tanaman 
Untuk dapat melihat seberapa besar penafsiran terhadap nilai koefisien korelasi kita dapat membandingkan nilai koefisien determinasi $\left(\mathrm{r}^{2}\right)$ yang merupakan fungsi kuadrat dari nilai koefisien korelasi atau $(0.728)^{2}=0.53$ hal ini menunjukan varians yang terjadi pada variable kelimpahan atau kejadian penyakit 53\% ditentukan oleh kelimpahan bakteri yang ada di rizosfer. Sebesar 47\% lainnya ditentukan oleh faktor lain seperti budidaya yang kurang baik dan lingkungan yang mendukung untuk terjadinya penyakit layu Fusarium.

Faktor sisa penyebab dari kelimpahan bakteri rizosfer tanaman pisang merupakan faktor lingkungan yang mendukung untuk perkembangan penyakit, yaitu $\mathrm{pH}$ tanah yang berkisar antara $4.4-6.8$, teknik budidaya petani yang belum mengikuti SOP budidaya pisang, dimana masih banyak petani yang menggunakan bibit yang berasal dari indukan yang diduga mengandung inokulum cendawan Foc. Kurangnya sanitasi lahan juga akan menyebabkan tanaman menjadi rentan karena adanya persaingan hara dengan tanaman lain di sekitarnya.

Seperti yang terjadi di salah satu kebun petani diwilayah AK 2 intensitas kejadian penyakit 70\% kelimpahan bakteri 58 untuk nilai $\mathrm{pH}$ tanah 5.7 kondisi kebun tanaman pisang tidak terawat lahan banyak gulma disekitar tanaman, diduga banyak mikroorganisme rizosfer tanah yang tergolong patogen sehingga membantu dalam terjadinya penyakit layu fusarium karena cendawan fusarium akan menyerang tanaman apabila tanaman tersebut dalam keadaan luka pada perakaran tanaman. Disini menunjukan bahwa kelimpahan bakteri rizosfer sangat berpengaruh dengan kejadian penyakit layu fusarium

Mikroorganisme tanah merupakan salah satu komponen biologi tanah, yang dapat dikelompokkan menjadi bakteri, actinomycetes, alga dan protozoa. Bakteri merupakan kelompok mikroorganisme tanah yang paling dominan dan mungkin meliputi separuh dari biomassa mikroba dalam tanah. Bakteri terdapat dalam segala macam tipe tanah tetapi populasinya menurun dengan bertambahnya kedalaman tanah. Secara umum profil horizon A terdiri dari lebih banyak mikroorganisme daripada horizon B dan C (Rao, 1995).

Zona tanah yang memberikan pengaruh paling dominan terhadap pertumbuhan tanaman adalah daerah perakaran atau yang disebut dengan rizosfer. Populasi mikroorganisme di rizosfer biasanya lebih banyak dan beragam dibandingkan pada tanah bukan rizosfer (Rosas et al., 2009). Mikroorganisme rizosfer dapat mempengaruhi pertumbuhan tanaman, baik menguntungkan atau menjadi patogen tanaman (Simatupang, 2008).

Menurut Nurhayati (2011), keberadaan mikroorganisme yang berada di rizosfer berpengaruh terhadap perkembangan patogen yang menyerang tanaman Keberadaan mikroorganisme ada yang bersifat negatif, ada juga yang bersifat positif dan ada juga yang bersifat netral bagi tanaman dan mikrootganisme lainnya. Keberadaan mikroorganisme disekitar tanaman ada yang bersifat negatif bagi patogen tanaman, sehingga digunakan oleh para ahli dalam pengendalian penyakit tanaman secara biologis.

Pengaruh positif mikroorganisme bagi patogen dapat berupa simbiosis, sehingga mampu meningkatkan aktivitas mikroorganisme patogen dalam menimbulkan penyakit pada tanaman. Pengaruh ysng netral antara mikroorganisme dengan patogen terjadi apabila keberadaan mikroorganisme tersebut tidak memberikan pengaruh baik positif maupun negatif terhadap patogen. Dari hasil penelitian ini diduga kelimpahan bakteri tidak dapat menekan kejadian penyakit layu Fusarium, karena tidak terdapat jenis bakteri yang bersifat antagonis terhadap Foc. Menurut Bais et al (2006), Bakteri yang ada di rizosfer juga ada yang dapat menimbulkan kerugian pada kesehatan tanaman, yaitu yang bersifat patogen atau parasit.

Luka yang terjadi akibat adanya serangan patogen lain pada akar juga merupakan jalan masuk yang lebar dan dapat menyebabkan kejadian dan keganasan penyakit yang parah (Jumjunidang et al., 2011). Pada pisang, penetrasi langsung tidak merupakan cara infeksi yang umum tapi melainkan karena adanya luka, yang merupakan hal penting untuk terjadinya layu pembuluh (Nasir et al., 2005).

\section{b. Hubungan keragaman bakteri rizosfer dengan kejadian penyakit layu fusarium}

Hasil analisis regresi dan korelasi antara keragaman dengan kejadian penyakit layu fusarium dengan bantuan software Minitab versi 16 menunjukkan hubungan seperti berikut ini :

$$
\mathrm{Y}==3.509-0.200 \mathrm{x}
$$

Dengan nilai $\mathrm{r}$ (koefisien korelasi) sebesar $=$. (0.057)

Dari hasil analisis korelasi diatas menunjukkan bahwa terjadi hubungan netatif antara 
keragaman bakteri rizosfer pisang dengan penyakit layu fusarium sebesar :-0.057.

Pada taraf kepercayaan 95\% dengan $n=9$ harga $r$ tabel $=0.666, r$ hitung menunjukan angka yang lebih kecil dari $r$ tabel $(-0.057<0.666)$. Sehingga $\mathrm{H}_{0}$ diterima dan $\mathrm{H}_{1}$ ditolakartinya.Artinya : "Tidak terdapat hubungan antara keragaman bakteri rizosfer dengan kejadian penyakit layu fusarium".

Untuk dapat melihat seberapa besar penafsiran terhadap nilai koefisien korelasi kita dapat membandingkan nilai koefisien determinasi $\left(\mathrm{r}^{2}\right)$ yang merupakan fungsi kuadrat dari nilai koefisien korelasi atau $(-0.057)^{2}=0.0032$ hal ini menunjukan bahwa varians yang terjadi pada variable keragaman atau kejadian penyakit $0.0032 \%$ ditentukan oleh faktor lain, keragaman bakteri yang ada di rizosfer tanah tanaman pisang ambon tidak memberikan pengaruh terhadap penyaikit layu fusarium. Sebesar $99.9968 \%$ kejadian penyakit layu fusarium ditentukan oleh faktor lain seperti dalam pengenceran tanah, sanitasi lahan yang tidak teratur sehingga gulma di sekitar tanaman utama mempengaruhi dalam perkembangan penyakit, $\mathrm{pH}$ tanah, dan ketinggian, dan bibit tanaman. Sehingga dalam keragaman bakteri rizosfer tanaman pisang tidak dapat menduganya.

Hubungan antara keragaman dengan kejadian penyakit memiliki hubungan yang negatif, dengan kata lain kedua variable penelitian yang penulis lakukan tidak memiliki kaitan erat dengan kejadian penyakit layu fusarium. Sebesar 99.9968\% faktor lain yang mempengaruhi pekembangan penyakit layu fusarium seperti faktor fisik dan faktor kimia tanah, faktor lingkungan, curah hujan, teknik budidaya petani.

Keberadaan penyakit tanaman menunjukkan bahwa tidak ada keseimbangan biologi dan jika ketidak seimbangan tersebut semakin besar menyebabkan penyakit semakin berkembang. Beberapa hal yang menyebabkan berkembangnya penyakit tanaman adalah patogen yang virulen, inokulum dalam jumlah yang banyak, lingkungan abiotik sesuai dengan patogen tetapi menekan perkembangan tanaman, tanaman yang sangat rentan dan antagonis tidak ada atau populasinya rendah (Baker \& Cook, 1974). Diantara keragaman bakteri yang didapat dari hasil penelitian ini, diduga rendahnya populasi bakteri rizosfer yang bersifat antagonis.

Kondisi ekologi tanah yang selalu dinamis dan kompleks merangsang mikroorganisme yang satu dengan yang lainnya saling

Kelimpahan Dan Keragaman Bakteri Rizosfer Tanaman Pisang Serta Hubungannya Dengan Kejadian Penyakit Layu Fusarium berinteraksi. Interaksi tersebut ada yang bersifat negatif (persaingan) dan positif (sinergi) (Baker \& Cook, 1974). Hasil pengamatan langsung di daerah pengambilan sampel tanah, pada lahan dengan intensitas tinggi seperti angke 1 dan angke 2 terlihat kondisi kebun yang tidak terawat, dengan sanitasi yang tidak baik ditandai dengan keberadaan gulma yang banyak, keberadaan gulma tentunya akan mempengaruhi kondisi tanaman ingang karena adanya persaingan nutrisi dengan tanaman utama.

Menurut Baker \& Cook (1974), eksudat akar telah diketahui meningkatkan biomassa dan aktivitas mikroba tanah dan fauna yang ditemukan di rizosfer. Eksudat akar memiliki pengaruh kualitatif dan kuantitatif terhadap mikroflora rizosfer. Akar tanaman mendukung pertumbuhan dan aktivitas dari berbagai spesies mikroorganisme yang memiliki pengaruh pada pertumbuhan dan/atau kesehatan tanaman. Diantara mikroorganisme ini, keragaman yang tinggi dari bakteri telah diidentifikasi dan dikategorisasi sebagai bakteri yang merugikan, menguntungkan atau netral dalam hubungannya dengan tanaman.

Lugtenberg et al., (1999) menyatakan bahwa mikroba tanah akan berkumpul di dekat perakaran tanaman (rizosfer) yang menghasilkan eksudat akar dan serpihan tudung akar sebagai sumber makanan mikroba tanah. Bila populasi mikroba di sekitar rizosfer didominasi oleh mikroba yang menguntungkan maka tanaman akan memperoleh manfaat yang besar dengan hadirnya mikroba tersebut. Menurut Bais et al (2006), Bakteri yang ada di rizosfer juga ada yang dapat menimbulkan kerugian pada kesehatan tanaman, yaitu yang bersifat patogen atau parasit.

\section{KESIMPULAN}

1. Dari hasil isolasi bakteri rizosfer pisang di 9 wilayah sentra penanaman pisang yaitu Angke 1, Angke 2, Balandongan, Baru, Kabandungan, Salapuncak, Gekbrong, Bungur dan Cisadang, didapatkan 31 koloni bakteri rizosfer.

2. Dari hasil penghitungan korelasi dan regresi, kelimpahan bakteri rizosfer tanaman pisang ambon menunjukan hubungan positif dengan kejadian penyakit layu fusarium sebesar : $(0.728)^{2}=$ 53\%. Hal ini bisa diartikan bahwa ketika kelimpahan bakteri rizosfer pisang tinggi maka serangan penyakit layu fusarium meningkat, hal ini diduga dari isolat

IRWAN IRAWAN dan WIDYA SARI 
bakteri yang didapat, tidak ada yang bersifat antagonis terhadap patogen penyebab penyakit layu fusarium pada pisang.

3. Terdapat hubungan negative antara keragaman bakteri rizosfer tanaman pisang ambon dengan kejadian penyakit layu fusarium sebesar : $(-0.057)^{2}=0.0032 \%$ - Hal ini bisa diartikan bahwa diduga keragaman bakteri rizosfer tidak dapat menekan kejadian penyakit layu Fusarium, karena tidak terdapat jenis bakteri yang bersifat antagonis terhadap layu fusarium.

\section{DAFTAR PUSTAKA}

Bais, H.P., T.L. Weir., L.G. Perry., S., Gilroy., J.M. Vivanco., 2006. The Role of Root Exudates In Rhizosphere Interactions With Plants and Other Organisms. Annual Review of Plant Biology Vol. 57: 233-266

Baker, K. F., \& Cook, R. J. 1974. Biological control of plant pathogens. WH Freeman and Company..

Balai Besar Pengkajian dan Pengembangan Teknologi Pertanian, 2008. Teknologi Budidaya Pisang. Bogor : Badan Penelitian dan Pengembangan Pertanian.

Husen, E. 2007. Pengambilan Contoh Tanah untuk Analisis Mikroba. In: Metode Analis Biologi Tanah. Balai Besar Penelitian dan Pengembangan Sumberdaya Lahan Pertanian. Bogor. 512 hal.

Jumjunidang, C. Hermanto, dan Riska, 2011. Virulensi Isolat Fusarium Oxysporum f sp. cubense VCG 01213/16 pada Pisang Barangan dari Varietas Pisang dan Lokasi yang Berbeda. J. Hort. 21(2) : 145-151

Kistler, H. C. 2001. Evolution of host specificity in Fusarium oxysporum. Fusarium, 7082.

Ladygina, N. 2005. Indirect Ecological Interaction on The Rhizosphere. Introductory Paper no 178. Dept of Ecology, Chemical Ecology and Ecotoxicology Lund Univ. Lund.

Lugtenberg, B. J., Kravchenko, L. V., \& Simons, M. 1999. Tomato seed and root exudate sugars: composition, utilization by Pseudomonas biocontrol strains and role in rhizosphere colonization. Environmental Microbiology, 1(5), 439-446.

Kelimpahan Dan Keragaman Bakteri Rizosfer Tanaman Pisang Serta Hubungannya Dengan Kejadian Penyakit Layu Fusarium
Nasir, N., Jumjunidang dan Riska, 2005. Deteksi dan Pemetaan Distribusi Fusarium Oxysporum f. sp. Cubense pada Daerah Potensial Pengembangan Agribisnis Pisang di Indonesia. J.Hort5 (1) : 50-57.

Natalia, 2005. Eksudat akar adalah asam amino, asam organik, karbohidrat, gula, vitamin, mucilage dan protein. http://repository.usu.ac.id/bitstream/1 23456789/34957/4/Chapter\%20II.pdf. Diakses pada tanggal 20 agustus 2014 $10.30 \mathrm{wib}$

Nurhayati, 2011. Ekesplorasi spasial cendawan tanah pada sekitar rizosfer tanaman jambu mete (anacardium occidentale l.) Di karangasem dan buleleng-bali. http:// www .google.co.id/

url? $\mathrm{sa}=\mathrm{t} \& \mathrm{rct}=\mathrm{j} \& \mathrm{q}=\& \operatorname{esrc}=\mathrm{s} \&$ source $=\mathrm{w}$ eb\&cd $=5 \& v e d=0 C D c Q F j A E \& u r l=h t t$ $\mathrm{p} \% 3 \mathrm{~A} \% 2 \mathrm{~F} \% 2 \mathrm{Foj}$.unud.ac.id $\% 2$ Findex. php $\% 2$ Fsimbiosis $\% 2$ Farticle $\% 2$ Fdownl oad $\% 2$ F7712\%2F5801\&ei=frTOU mL

KsWjugSj-

ICgAg\&usg=AFQjCNH1EeQSZ2M2D FhgOta 5kAAeSakTQ\&bvm=bv. 73373 277,d.c2E. Diakses pada tanggal 20 agustus 201410.30 wib

Ploetz \& pegg, 1997. Panama disease : A classic and destructive disease of banana. Online. Plant Health Progress doi:10.1094/PHP2000-1204-01-HM. http:// www. plantmanagementnetwork. org/ pub/php/ management/ banana panama/. Diakses pada tanggal 20 agustus $201410.30 \mathrm{wib}$

Ploetz, R. C., \& Pegg, K. G. 2000. Fusarium wilt. Diseases of banana, abaca and Enset. DR Jones, ed. CABI Publishing, Wallingford, UK, 143-159.

Pusat Data dan Informasi Pertanian, 2009. Analisis Konsumsi Pangan. Jakarta : Pusat Data dan Informasi Pertanian, Departemen Pertanian. (hal 96-101).

Rao, N. S. 1995. Soil microorganisms and plant growth (No. Ed. 3). Science Publishers, Inc..

Rosas, S. B., Avanzini, G., Carlier, E., Pasluosta, C., Pastor, N., \& Rovera, M. 2009. Root colonization and growth promotion of wheat and maize by Pseudomonas aurantiaca SR1. Soil Biology and Biochemistry, 41(9), 1802-1806.

Simatupang, DS. 2008. Berbagai Mikroorganisme Rizosfer pada Tanaman Pepaya (Carica papaya L.) di 
Pusat Kajian Buah-buahan Tropika (PKBT) IPB Desa Ciomas, Kecamatan Pasirkuda, Kabupaten Bogor, Jawa Barat. [Skripsi]. Institut Pertanian Bogor, Bogor.

Sunatmo, T. I. 2009. Eksperimen mikrobiologi dalam laboratorium. Jakarta (ID): Ardy Agency 